\title{
Macrofaunal assemblages associated with coralline turf: species turnover and changes in structure at different spatial scales
}

\author{
María G. Liuzzi, Juan López Gappa* \\ Museo Argentino de Ciencias Naturales, Av. Angel Gallardo 470, Buenos Aires C1405DJR, Argentina
}

\begin{abstract}
Our aim was to analyse changes in species turnover and structure of macrofaunal assemblages associated with intertidal coralline algal turfs at 4 spatial scales along the coast of Argentina (southwestern Atlantic): provinces $\left(\sim 10^{6} \mathrm{~m}\right)$, localities $\left(\sim 10^{4} \mathrm{~m}\right)$, sites $\left(\sim 10^{2} \mathrm{~m}\right)$ and replicate quadrats $(\sim 1$ to $3 \mathrm{~m})$. Corallina officinalis was by far the dominant algal species in most samples, but C. elongata and Jania rubens var. rubens were also frequent. Frond density was 3 times higher in the southern, cold-temperate Chubut province than in the northern, warm-temperate Buenos Aires province. Macrofaunal species richness, diversity and evenness were also significantly higher in samples from Chubut than in those from Buenos Aires, with 'province' explaining 86 to $98 \%$ of the variance in the analytical model. In total, 118 macrofaunal taxa belonging to 11 invertebrate phyla were found. Mytilid bivalves and polychaetes were the most important groups contributing to differences between provinces. Brachidontes rodriguezii was extremely abundant in Buenos Aires province, while Rhynchospio glutaea and Perumytilus purpuratus were dominant in samples from Chubut. Changes in assemblage structure were significant at the scale of provinces, localities and sites in Patagonian localities. Measures of beta diversity showed that taxonomic turnover was correlated with distance between samples at scales of $10^{4} \mathrm{~m}$ or higher, with the highest at the scale of provinces. Higher biodiversity in the Magellan assemblage than in warmer areas of the northern coast of Argentina may be related to the Pacific origin of the Magellan fauna, which entered the southwestern Atlantic during the Tertiary period.
\end{abstract}

KEY WORDS: Coralline turf $\cdot$ Beta diversity $\cdot$ Latitudinal trends of biodiversity $\cdot$ Spatial scales $\cdot$ Rocky intertidal $\cdot$ Corallina $\cdot$ Argentina

\section{INTRODUCTION}

Branching coralline algae provide shelter from desiccation stress, wave action and predation to rich and diverse macrofaunal assemblages by modifying the environment with their own living and dead tissues, and thus can be regarded as autogenic ecosystem engineers (Jones et al. 1994, Daleo et al. 2006). In harsh environments, intertidal coralline algal turfs ameliorate extreme physical conditions, allowing the presence of many infaunal and epifaunal species that otherwise would be absent at this shore level (Bertness et al. 2006). Physical structure and complexity of the habitat, among other factors, have a major influence on the biodiversity of these assemblages (Kelaher 2002, 2003, Kelaher et al. 2003, 2007).

Understanding the role of scale is important to ecologists, since the way in which nature varies can affect both our ability to measure a particular phenomenon and our perception of its causes (Denny et al. 2004). In the intertidal zone, there is significant variation in diversity and abundance of molluscs among patches of coralline turf separated by 10s of meters (Kelaher et al. 2004,2007 ). At a continental scale, richness of molluscan species and total abundances of individuals associated with coralline algae are greater on Australian 
than on European and South American shores (Kelaher et al. 2004). As coralline algae provide habitat for a large number of small invertebrates (Chapman et al. 2005, Bussell et al. 2007) and occur along 1000s of km of shoreline, they may be useful in studies analysing changes in benthic biodiversity and taxonomic turnover at different spatial scales.

Species diversity has been partitioned into different components. Beta diversity, i.e. the extent of change in species composition among the samples of a data set (Whittaker 1975, Gray 2000), describes taxonomic turnover in assemblages at various spatial scales within a habitat (Winberg et al. 2007). A vast array of measures to assess beta diversity has been proposed (Koleff et al. 2003), some of which are used to analyse the degree of taxonomic change in the benthic environment (Ellingsen 2002).

Latitudinal gradients in species richness are well documented in terrestrial ecosystems (Rosenzweig 1995). In the marine realm, however, the existence of a latitudinal cline for the shallow water fauna is debatable. In the northern hemisphere, the numbers of species of bivalves (Roy et al. 2000) and prosobranch gastropods (Roy et al. 1998) decrease with increasing latitude, but no convincing evidence of a diversity cline in soft-sediment macrobenthos was found within a $15^{\circ}$ latitudinal gradient along the Norwegian coast (Ellingsen \& Gray 2002). In the southern hemisphere, there are no signs of a cline of increasing richness from the Antarctic to the tropics (Clarke 1992, Gray 1997, 2001). A long history of geographic isolation is thought to be the cause of the high levels of diversity and endemism observed in many Antarctic taxa (Clarke 1992). Beyond the Antarctic Convergence, coastal biogeographic provinces in the southwestern Atlantic are indirectly influenced by warm-temperate (Brazil) and sub-Antarctic (Malvinas/Falkland) currents flowing in opposite directions (Piola \& Rivas 1997). The biodiversity patterns across the transition between cold- and warm-temperate water masses along the Atlantic coast of southern South America, however, have not yet been fully explored. Therefore, the main aim of this study was to analyse species turnover and changes in structure in macrofaunal assemblages associated with intertidal coralline algae at different spatial scales across a biogeographic transition zone in the southwestern Atlantic.

\section{MATERIALS AND METHODS}

Intertidal sampling was performed from April 4 to May 8, 2005. Changes in assemblage structure and species turnover were analysed at 4 spatial scales: provinces $\left(\sim 1.1 \times 10^{6} \mathrm{~m}\right)$, localities $\left(\sim 1.0\right.$ to $\left.1.5 \times 10^{4} \mathrm{~m}\right)$, sites ( 100 to $200 \mathrm{~m}$ ) and replicate quadrats ( 1 to $3 \mathrm{~m})$ (Fig. 1, Table 1). For the largest scale, we chose Buenos Aires and Chubut provinces. The former is under the indirect influence of the warm-temperate Brazil Current and has been regarded as the southernmost district of the Argentine Zoogeographic Province, while the latter is influenced by cold-temperate waters and belongs to what is traditionally called the Patagonian district of the Magellanic Zoogeographic Province (Bastida et al. 1992).

All localities were relatively exposed to wave action. Intertidal substrata consisted of mudstone platforms in Buenos Aires province (López Gappa \& Tablado 1997) and consolidated limestone in Chubut province (Bertness et al. 2006). The localities chosen in Buenos Aires province were Quequén and Necochea (Fig. 1). Sampling at Quequén took place in an area called Bahía de los Vientos located approximately $3.5 \mathrm{~km}$ east of Quequén Harbour, which lies in the mouth of the Quequén Grande river. Sampling at Necochea was performed approximately $11.4 \mathrm{~km}$ west of the city of Necochea in an area locally known as Punta Negra. The localities chosen in Chubut province were Comodoro Rivadavia and Rada Tilly, where sampling took place on intertidal platforms located near urban areas. Comodoro Rivadavia sites lie $1.3 \mathrm{~km}$ southwest of Comodoro Rivadavia harbour (Fig. 1).

Two sites separated by distances of $119 \mathrm{~m}$ to $181 \mathrm{~m}$ were chosen randomly at each locality. GPS coordinates were recorded at each site and a matrix of pairwise distances between each combination of sites was built using a Geographic Information System software. Sampling was restricted to lower intertidal areas with $100 \%$ coverage by coralline turf. Five $10 \mathrm{~cm} \times 10 \mathrm{~cm}$ quadrats were selected randomly and scraped clear with a scraper, giving a total of 40 samples (2 provinces $\times 2$ localities $\times 2$ sites $\times 5$ quadrats). Replicate quadrats were spaced approximately 1 to $3 \mathrm{~m}$ apart from one another.

Samples were fixed in $4 \%$ formalin and later transferred to $70 \%$ ethanol in the laboratory. Organisms were separated from the muddy sediment using a $62 \mu \mathrm{m}$ sieve, sorted and identified to the lowest taxonomic level possible. Meiofaunal organisms (mainly nematodes, harpacticoid copepods and oligochaetes) and microscopic epiphytes associated with corallines, such as diatoms and algal germlings, were not taken into account. Colonial taxa were counted as number of colonies or fragments of colonies.

After separation of all associated invertebrates, coralline algae were air-dried to constant weight ( $3 \mathrm{~d}$ ). Algae were weighed to the nearest milligram on a Chyo JK-180 analytical balance. The average length of fronds was determined from measurements of length on 15 randomly selected dried fronds per site, using 


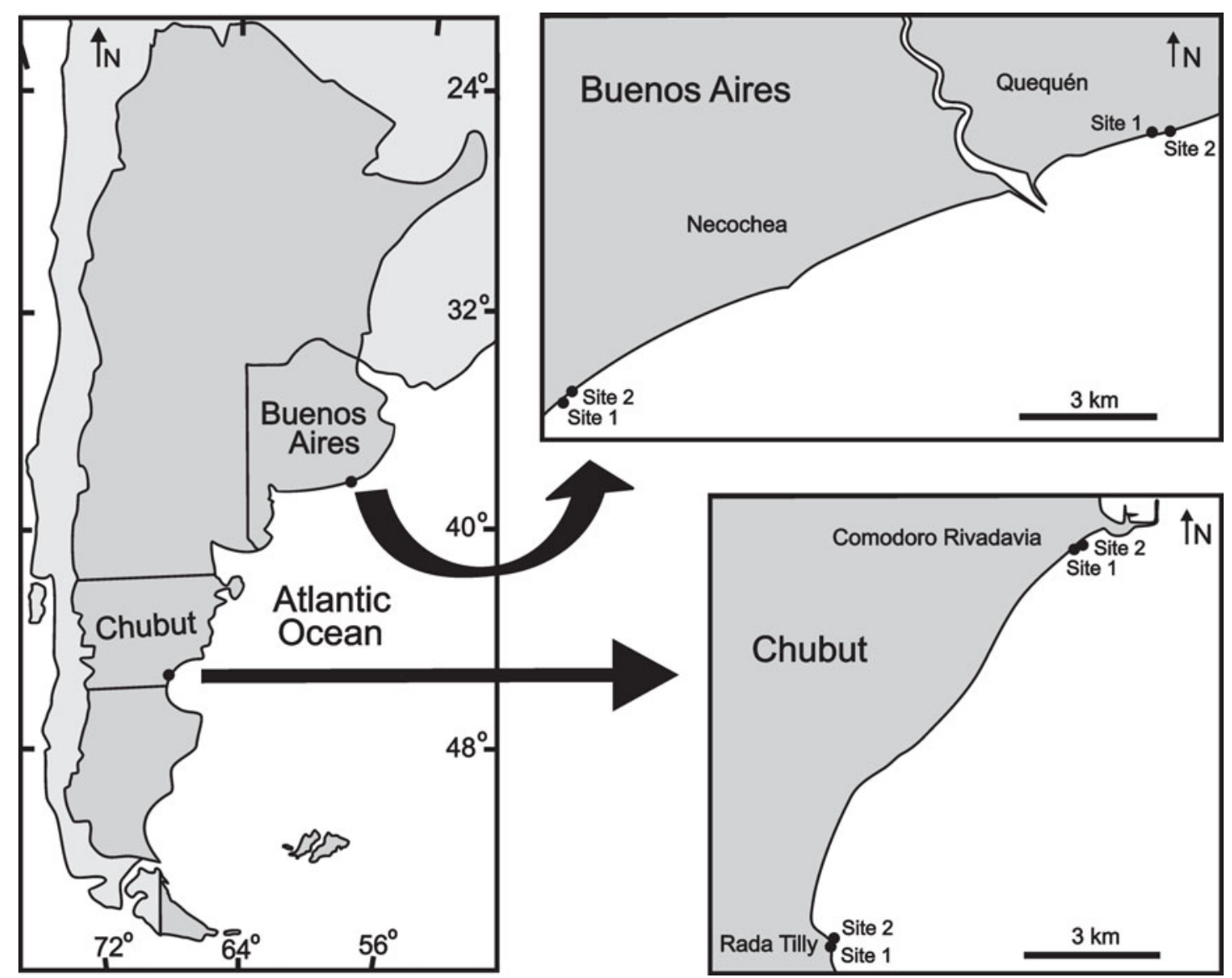

Fig. 1. Study area showing the location of provinces, localities and sites

Table 1. Geographic locations of sites sampled within provinces (Buenos Aires and Chubut) and their respective localities

\begin{tabular}{|c|c|c|c|c|}
\hline & \multicolumn{2}{|c|}{ Buenos Aires } & \multirow{2}{*}{$\begin{array}{c}\text { Chubut } \\
\text { Comodoro Rivadavia }\end{array}$} & \multirow[b]{2}{*}{ Rada Tilly } \\
\hline & Quequén & Necochea & & \\
\hline \multirow[t]{2}{*}{ Site 1} & $38^{\circ} 34.241^{\prime} \mathrm{S}$ & $38^{\circ} 37.142^{\prime} \mathrm{S}$ & $45^{\circ} 52.059^{\prime} \mathrm{S}$ & $45^{\circ} 56.864^{\prime} \mathrm{S}$ \\
\hline & $58^{\circ} 39.897^{\prime} \mathrm{W}$ & $58^{\circ} 49.318^{\prime} \mathrm{W}$ & $67^{\circ} 28.443^{\prime} \mathrm{W}$ & $67^{\circ} 32.803^{\prime} \mathrm{W}$ \\
\hline \multirow[t]{2}{*}{ Site 2} & $38^{\circ} 34.223^{\prime} \mathrm{S}$ & $38^{\circ} 37.085^{\prime} \mathrm{S}$ & $45^{\circ} 52.017^{\prime} \mathrm{S}$ & $45^{\circ} 56.800^{\prime} \mathrm{S}$ \\
\hline & $58^{\circ} 39.801^{\prime} \mathrm{W}$ & $58^{\circ} 49.217^{\prime} \mathrm{W}$ & $67^{\circ} 28.336^{\prime} \mathrm{W}$ & $67^{\circ} 32.798^{\prime} \mathrm{W}$ \\
\hline
\end{tabular}

only complete fronds with intact holdfasts. Following several ecological studies on coralline turfs (Kelaher 2003, Kelaher et al. 2003, 2007), density of fronds was estimated indirectly by dividing the dry weight of coralline fronds per $100 \mathrm{~cm}^{2}$ by the average length of fronds $(\mathrm{cm})$. This surrogate measure of density (units of g $100 \mathrm{~cm}^{-3}$ ) was shown to be a good representation of the actual number of fronds per unit area, which is very difficult to measure directly.

Species richness, diversity (Shannon-Wiener's $H^{\prime}$, log base e) and evenness (Pielou's $J^{\prime}$ ) of each sample were calculated with the DIVERSE routine of the
PRIMER package (Clarke \& Warwick 1994) based on the number of individuals or colonies per $100 \mathrm{~cm}^{2}$ of coralline algae. All these macrofaunal variables, as well as frond density, were analysed at different spatial scales using a nested ANOVA model. Factor 1 was Province (fixed, crossed), with 2 levels. Factor 2 was Locality (fixed, nested in Province), with 2 levels. Factor 3 was Site (random, nested in Province and Locality), with 2 levels. Homogeneity of variances was verified with the Cochran's $C$-test. To stabilise variances, frond density and species richness data were log- and square roottransformed, respectively.

The expected mean squares and the sums of squares for each of the nested factors in the ANOVA were used to determine the proportional contribution of each scale $\left(\omega^{2}\right)$ to overall variation (Graham \& Edwards 2001, Winberg et al. 2007). Only in the case of frond density did we encounter negative estimates of components of variance at the scales of localities and sites. 
Following Fletcher \& Underwood (2002), negative estimates were set to zero, the corresponding factors were removed from the model and the estimates of the remaining factors were re-calculated.

Beta diversity was estimated in 2 different ways: (1) similarity between all pairs of samples was calculated based on a presence/absence matrix of all 118 species using the Bray-Curtis coefficient, which in this case is algebraically equivalent to the Sörensen index (see Clarke \& Warwick 1994); (2) the magnitude of species gains and losses between each pair of samples was measured with the coefficient $\beta_{\operatorname{sim}}=\min (b, c) /[\min (b$, $c)+a]$, where $a$ is the total number of shared species between 2 samples, $b$ is the number of species present in the second sample but absent from the first sample, and $c$ is the number of species present in the first sample but absent from the second sample (Koleff et al. 2003). Measures of beta diversity were plotted against distance separating each pair of samples.

As variances of Bray-Curtis similarity data across different scales were heterogeneous and could not be stabilised after several transformations, the nonparametric Kruskal-Wallis test was used instead of ANOVA. A posteriori pairwise comparisons were carried out with the Dunn test (Zar 1996).

Species richness was visualized in species-sample accumulation curves (999 randomisations) using the

Table 2. Summaries of ANOVAs comparing density of coralline fronds, macrofaunal species richness, diversity and evenness. $\omega^{2}$ and $\%$ values indicate the proportional contribution of each factor to the total variance in the model. Pr: province, Lo: locality, Si: site. Density was log-transformed and species richness was square root-transformed to stabilise variances

\begin{tabular}{|c|c|c|c|c|c|c|}
\hline Factor & df & MS & $F$ & $\mathrm{p}$ & $\omega^{2}$ & $\%$ \\
\hline \multicolumn{7}{|c|}{ Density of coralline fronds $\left(\mathrm{g} 100 \mathrm{~cm}^{-3}\right)$} \\
\hline $\operatorname{Pr}$ & 1 & 1.4687 & 57.375 & $<1 \times 10^{-6}$ & 0.144 & 84.9 \\
\hline Residual & 38 & 0.0256 & & & 0.026 & 15.1 \\
\hline Total & 39 & & & & 0.170 & \\
\hline \multicolumn{7}{|c|}{ Species richness } \\
\hline $\mathrm{Pr}$ & 1 & 63.4884 & 210.146 & 0.0001 & 6.319 & 86.5 \\
\hline Lo $(\mathrm{Pr})$ & 2 & 8.6740 & 28.711 & 0.0042 & 0.837 & 11.4 \\
\hline $\mathrm{Si}(\mathrm{Lo}(\mathrm{Pr}))$ & 4 & 0.3021 & 2.643 & 0.0516 & 0.038 & 0.5 \\
\hline Residual & 32 & 0.1143 & & & 0.114 & 1.6 \\
\hline Total & 39 & & & & 7.308 & \\
\hline \multicolumn{7}{|c|}{ Diversity (Shannon-Wiener's $H^{\prime}$ ) } \\
\hline $\operatorname{Pr}$ & 1 & 33.2125 & 629.780 & $<0.0001$ & 3.316 & 97.1 \\
\hline Lo (Pr) & 2 & 0.7414 & 14.059 & 0.0155 & 0.069 & 2.0 \\
\hline $\mathrm{Si}(\mathrm{Lo}(\operatorname{Pr}))$ & 4 & 0.0527 & 2.119 & 0.1013 & 0.006 & 0.2 \\
\hline Residual & 32 & 0.0249 & & & 0.025 & 0.7 \\
\hline Total & 39 & & & & 3.416 & \\
\hline \multicolumn{7}{|c|}{ Evenness (Pielou's $J^{\prime}$ ) } \\
\hline $\operatorname{Pr}$ & 1 & 1.9089 & 532.972 & $<0.0001$ & 0.191 & 97.9 \\
\hline Lo (Pr) & 2 & 0.0135 & 3.760 & 0.1206 & 0.001 & 0.5 \\
\hline $\mathrm{Si}(\mathrm{Lo}(\mathrm{Pr}))$ & 4 & 0.0036 & 1.163 & 0.3456 & 0.000 & 0.0 \\
\hline Residual & 32 & 0.0031 & & & 0.003 & 1.6 \\
\hline Total & 39 & & & & 0.195 & \\
\hline
\end{tabular}

PRIMER software package (Clarke \& Warwick 1994).

Changes in structure across scales were analysed with a combination of hierarchical agglomerative clustering using group-average linking, non-metric Multidimensional Scaling (MDS), and one-way analysis of similarities (ANOSIM) on a Bray-Curtis similarity matrix (Clarke \& Warwick 1994). Only 92 species occurring in more than 1 sample were included in these analyses. Abundance (number of individuals/colonies) of each taxon was 4 th-root transformed to reduce the influence of dominant species. The SIMPER routine was used to determine which species made the greatest contributions to dissimilarity in significant contrasts between provinces, localities and sites.

\section{RESULTS}

Coralline turfs comprised a mixture of 4 species of articulated coralline algae. Corallina officinalis L. was by far the dominant species in most samples (36/40) from Buenos Aires and Chubut provinces. Jania rubens (L.) Lamouroux var. rubens Irvine \& Johansen occurred only in Buenos Aires province (see Mendoza 2002), and was usually less abundant than $C$. officinalis, except in 4 samples from Necochea. C. elongata Ellis \& Solander occurred only in Chubut province, usually comprising less than $20 \%$ of the turf. Fragments of Bossiella orbigniana (Decaisne) Silva appeared in just one sample from Rada Tilly.

Coralline frond density varied significantly only at the scale of provinces, which explained $85 \%$ of the total variance in the model (Table 2), and was 3 times higher in samples from Chubut than from Buenos Aires (Fig. 2a). A substantial proportion (15\%) of total variation in frond density occurred at the scale of replicate quadrats (Table 2). Changes in frond density between provinces were mainly due to changes in algal weight per unit area, since variations in the lengths of fronds at the scale of provinces did not reach statistical significance (ANOVA, $F_{1,4}=7.66, \mathrm{p}>0.05$ ).

Differences in macrofaunal species richness were significant at the scales of provinces and localities, which explained $86 \%$ and $11 \%$ of the total variance, respectively (Table 2). At the scale of provinces, species richness in Chubut was double that in Buenos Aires. At the scale of localities, species richness at Quequén was double that at 

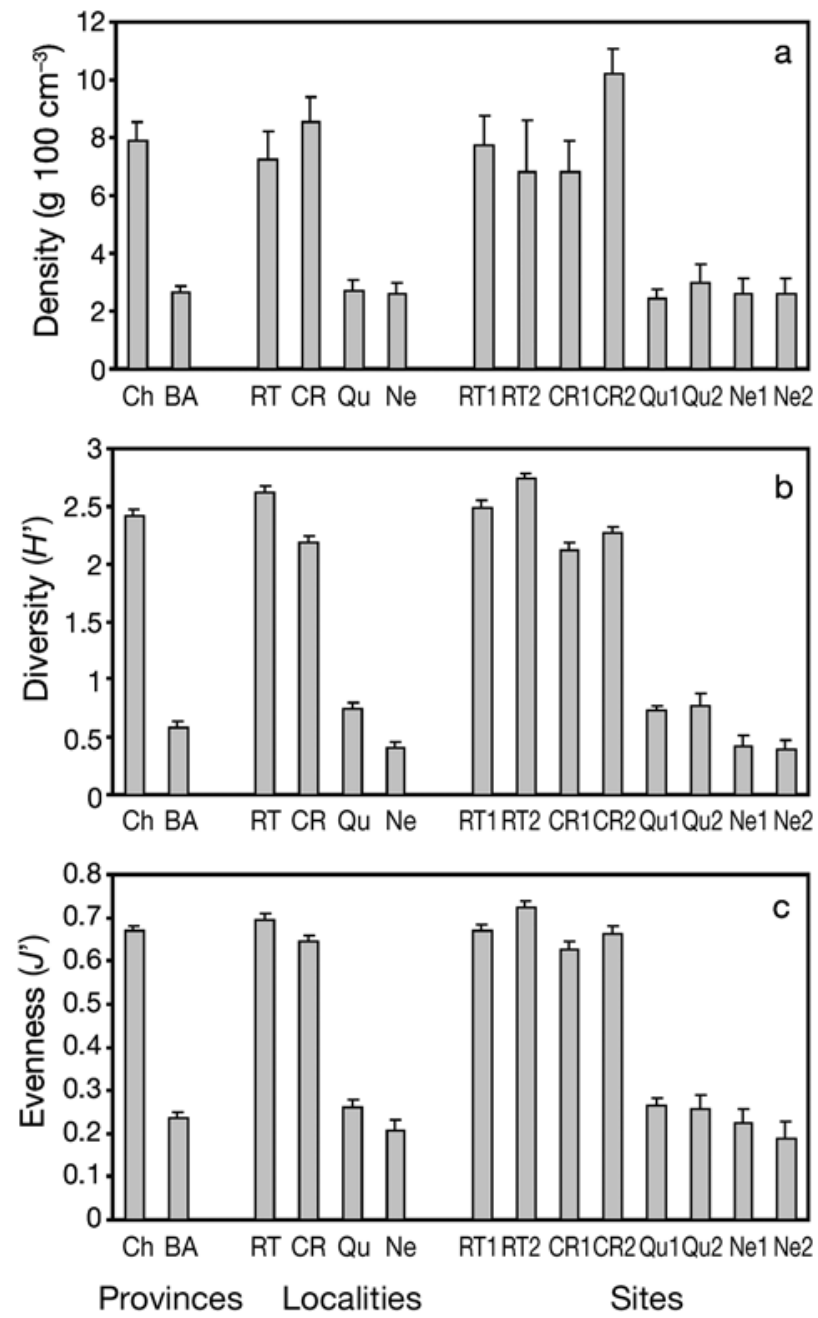

Fig. 2. Comparison of (a) density of coralline fronds, (b) diversity and (c) evenness of the macrofaunal assemblages between provinces, localities and sites (mean $+\mathrm{SE}$ ). Ch: Chubut, BA: Buenos Aires, RT: Rada Tilly, CR: Comodoro Rivadavia, Qu: Quequén, Ne: Necochea

Necochea, and $40 \%$ higher at Rada Tilly than at Comodoro Rivadavia (Fig. 3). Sites and replicate quadrats accounted for only $0.5 \%$ and $1.6 \%$ of the total variance in species richness, respectively.

Macrofaunal diversity values varied significantly at the scale of provinces and localities, which explained $97 \%$ and $2 \%$ of the total variance in the model, respectively. Variance at the scale of sites and replicate quadrats was very low (Table 2). Diversity was more than 4 times higher in Chubut than in Buenos Aires, $80 \%$ higher at Quequén than at Necochea and 20\% higher at Rada Tilly than at Comodoro Rivadavia (Fig. 2b).

Evenness differed significantly only at the scale of provinces, which explained almost all the variance in the model (Table 2). Evenness values were almost

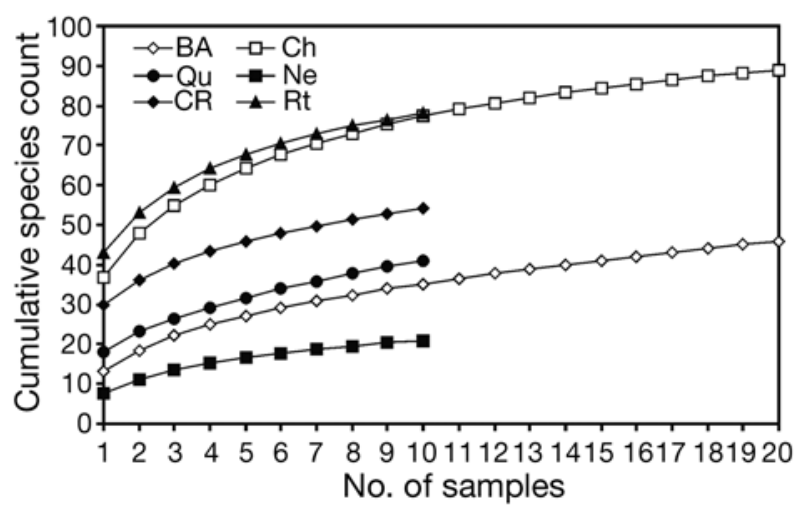

Fig. 3. Species accumulation curves for provinces and localities. Plotted values are means based on 999 randomisations. Abbreviations as in Fig. 2

3 times higher in samples from Chubut than from Buenos Aires (Fig. 2c), due to the extremely high abundance (up to 284000 ind $\mathrm{m}^{-2}$ ) of Brachidontes rodriguezii in the latter. Changes in diversity and evenness at the scale of replicate quadrats accounted for a very low proportion of the total variance in the model (Table 2).

Density of macrofauna varied from 46500 to 304400 ind. $\mathrm{m}^{-2}$. Macrofaunal assemblages comprised 118 taxa belonging to 11 invertebrate phyla. Polychaetes, arthropods and molluscs were the most specious groups, with 40,26 and 21 taxa, respectively. The majority of individuals belonged to Mollusca and Polychaeta, due to the abundance of the mytilid Brachidontes rodriguezii in Buenos Aires and the spionid Rhynchospio glutaea in Chubut.

Both measures of beta diversity calculated on presence/absence data were significantly correlated with distance between samples. The degree of taxonomic turnover was low to moderate at the scales of samples collected at the same site, at different sites from the same locality and at different localities from the same province, but was highest between samples belonging to different provinces (Fig. 4), which had only 17 species in common $(14.4 \%)$. When the largest scale (samples belonging to different provinces) was not taken into account in the analysis, the correlation between distance and taxonomic turnover still remained significant when measured with the Bray-Curtis index $(\mathrm{r}=$ $\left.-0.64, \mathrm{p}<1 \times 10^{-6}\right)$, but not with the $\beta_{\text {sim }}$ index $(\mathrm{r}=$ $-0.02, p=0.70$ ), suggesting that Bray-Curtis similarity is a more sensitive measure of taxonomic turnover than $\beta_{\text {sim. }}$. The relationship between beta diversity and distance was further explored using the Kruskal-Wallis non-parametric test. Variance at the scale of provinces was an order of magnitude lower than at the 3 smallest scales, meaning that Bray-Curtis similarity between 


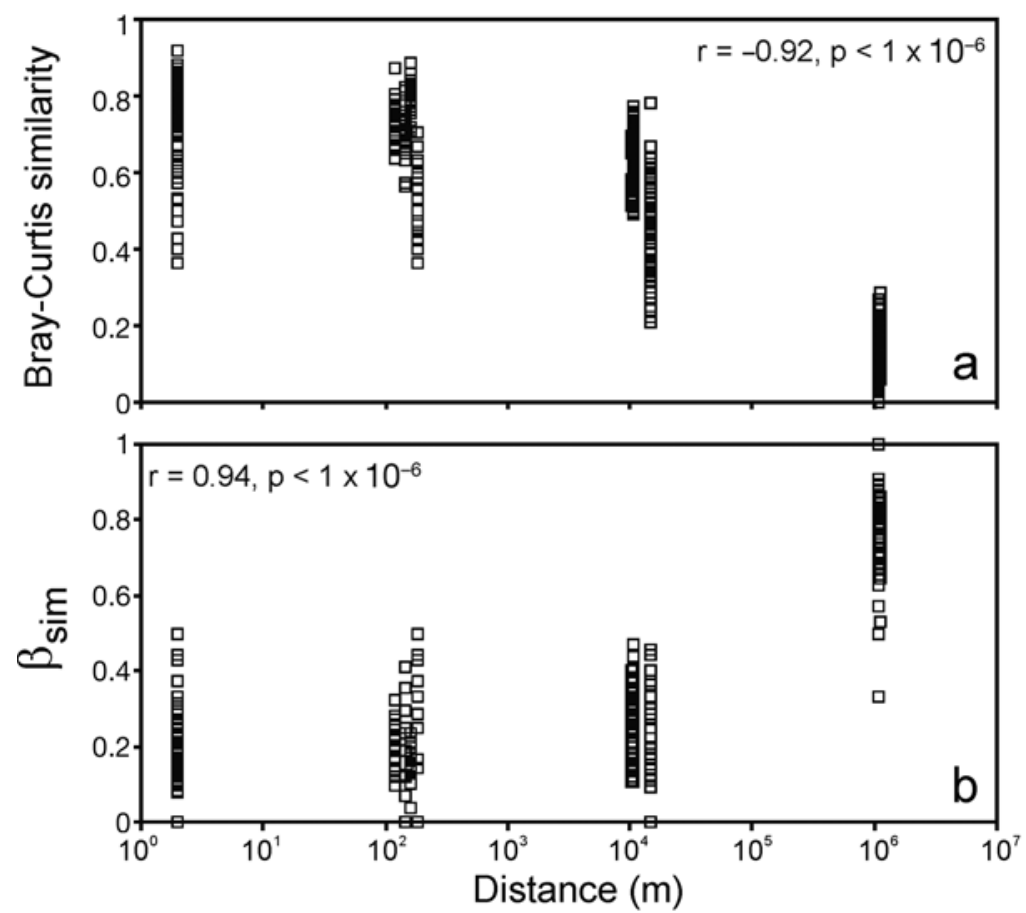

Fig. 4. Relationship between measures of beta diversity and distance among samples of coralline turf $(\mathrm{n}=780)$. (a) Bray-Curtis similarity, (b) $\beta_{\text {sim }}$. $\mathrm{r}$ : product-moment correlation coefficient. Distances between replicate quadrats within the same site were arbitrarily set to $2 \mathrm{~m}$ samples separated by $10^{6} \mathrm{~m}$ was uniformly low, while similarity at the 3 smallest scales was not only relatively high but also more variable (see Fig. 4a). As expected, values of the Bray-Curtis index varied significantly across scales (Kruskal-Wallis test, $H=616.2$, p < 0.001). A posteriori pairwise comparisons showed that all scales differed significantly between one another (Dunn test, p $<0.05$ ) except the 2 lowest scales (samples collected at the same site or at different sites within the same locality, Dunn test, $\mathrm{p}>0.05$ ).

Provinces and localities were perfectly separated in the dendrogram based on 4th-root transformed abundances of 92 macrobenthic species, but samples belonging to different sites were to some extent mixed in the low-order clusters and in the MDS ordination, particularly those from both warm-temperate localities (Fig. 5).

ANOSIM tests showed that changes in structure were highly significant at the scale of provinces and localities. Sites dif-
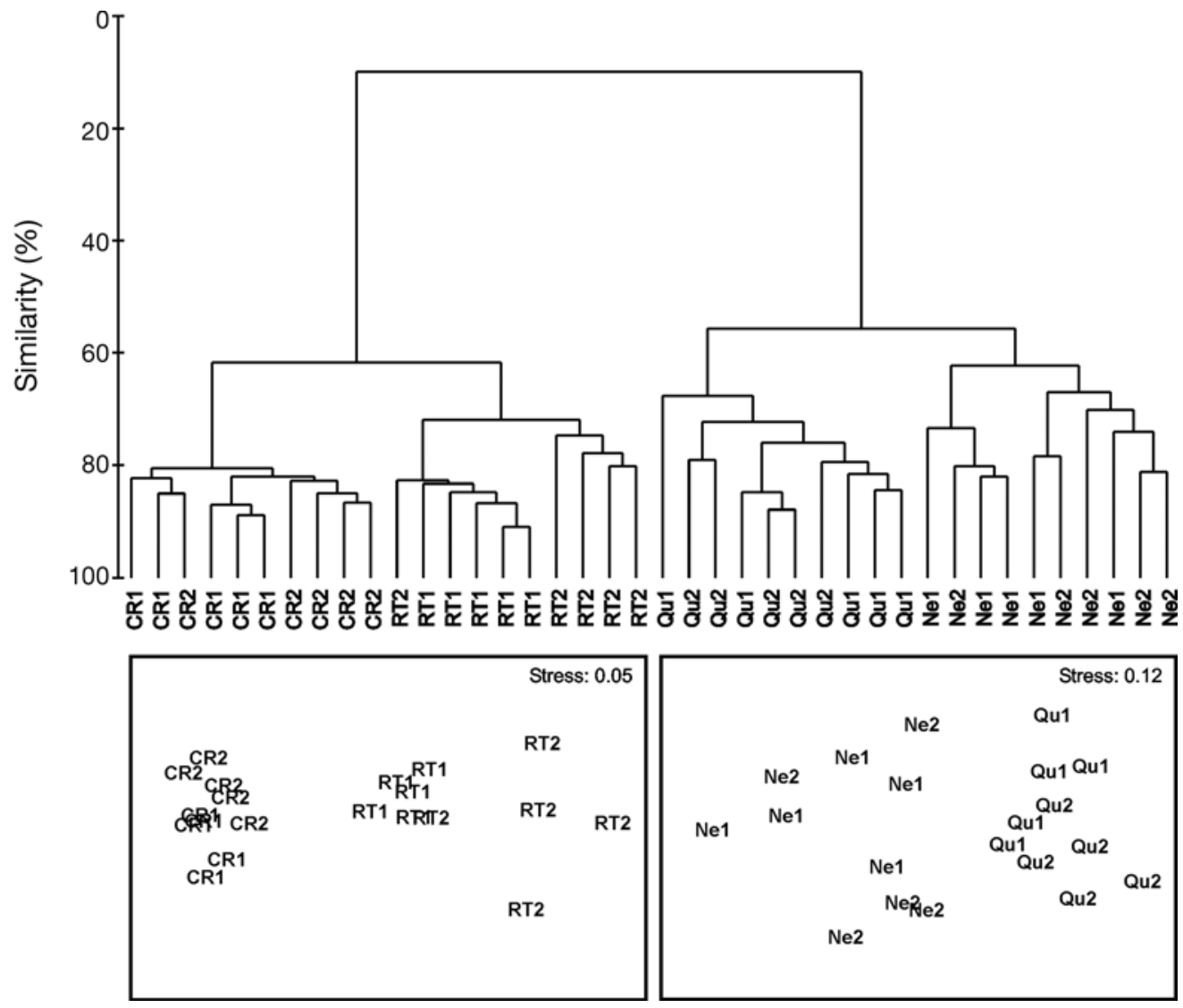

Fig. 5. Cluster analysis using group-average linking (top panel) and non-metric multidimensional scaling ordination (2 lower panels) based on Bray-Curtis similarities. Abundances of 92 macrobenthic species were 4th-root transformed. Abbreviations as in Fig. 2 
fered significantly only in Comodoro Rivadavia and Rada Tilly but not in Necochea and Quequén (Table 3).

SIMPER (Table 4) showed that mytilids and polychaetes were the most important groups contributing to the significant difference between provinces. Brachidontes rodriguezii was extremely abundant in samples from Buenos Aires but was absent in Chubut. On the other hand, Perumytilus purpuratus was found only in Chubut and not in Buenos Aires. Several spionid, cirratulid, syllid, nereidid, orbinid, eunicid, terebellid and capitellid polychaetes, together with isopods and nemerteans were also abundant in Chubut but rare or absent in Buenos Aires.

Nemerteans, tanaidaceans, solitary ascidians, decapods, planarians, polychaetes and amphipods were more abundant at Quequén than at Necochea. Differences in structure between Comodoro Rivadavia and Rada Tilly were more subtle and difficult to interpret since no species made a major individual contribution to dissimilarity. Species accounting for significant differences between sites at Comodoro Rivadavia and Rada Tilly (not listed in Table 4) also made very small and gradual contributions to overall dissimilarity.

\section{DISCUSSION}

Diversity and species richness of macrofaunal assemblages associated with coralline turf, as well as density of coralline fronds, were significantly higher in a coldtemperate than in a warm-temperate region of the southwestern Atlantic. Lower macrofaunal diversity in loosely-packed than in densely-packed coralline turf was partially due to the extreme abundance of juveniles of the small mytilid Brachidontes rodriguezii recruiting on low intertidal rocky shores of Buenos Aires province, which caused a remarkable decrease in the evenness component of diversity. It is well known that juveniles of other mytilids settle on filamentous red algae before attaching to adult mussel beds (e.g. Bayne 1964). Low intertidal coralline turfs may therefore act as a temporary reservoir of newly-settled plantigrades

Table 3. ANOSIM test contrasts between provinces, localities and sites

\begin{tabular}{|lcr|}
\hline Contrast & $\mathrm{R}$ & $\mathrm{p}$ \\
\hline Buenos Aires - Chubut & 1.000 & $<0.001$ \\
Quequén - Necochea & 0.799 & $<0.001$ \\
Comodoro Rivadavia - Rada Tilly & 0.926 & $<0.001$ \\
Quequén sites & 0.260 & 0.056 \\
Necochea sites & 0.132 & 0.206 \\
Comodoro Rivadavia sites & 0.444 & 0.016 \\
Rada Tilly sites & 0.616 & 0.008 \\
\hline
\end{tabular}

that will later detach themselves and undergo a secondary settlement phase on mid intertidal beds dominated by adults of their own species.

Both diversity and species richness were lower in Buenos Aires than in Chubut provinces. Factors operating at the biogeographic scale, such as a smaller species pool at lower than at higher latitudes off Argentina may be responsible for this pattern. Biogeographic analyses of several macrobenthic groups in the southwestern Atlantic have shown that species richness is higher in the cold-temperate Magellan region than in warm-temperate waters at lower latitudes (Bastida et al. 1992, López Gappa 2000, López Gappa et al. 2006). Similarly, a review of Chilean benthic nearshore ecosystems suggested that there is a biodiversity hotspot south of $42^{\circ} \mathrm{S}$ in the southeastern Pacific (Fernández et al. 2000, Valdovinos et al. 2003). Studies on the evolution of Cenozoic seaways in the circum-Antarctic region support the hypothesis that the Magellan biota entered the southwestern Atlantic during the Tertiary period after the Drake Passage opened to deep water circulation during the Eocene-Oligocene boundary ( 31 to $32 \mathrm{Ma}$ ) (Lawver \& Gahagan 2003). A biogeographic analysis of the Miocene molluscan faunas of Argentina and Uruguay (Martínez \& del Río 2002) concluded that after the development of the cold Malvinas/Falkland Current, the dominant Caribbean elements became extinct or moved northwards. According to that study (op. cit.), the Argentine Biogeographic Province (i.e. southern Brazil, Uruguay and the Argentine coast north of 42 to $43^{\circ} \mathrm{S}$ ) should be regarded as a transitional assemblage between the Magellanic and Brazilian Biogeographic Provinces.

Changes in assemblage structure at the scale of localities and, in some instances, between sites, were of a much smaller magnitude than those observed between provinces, and may be attributed to small differences in habitat topography, intertidal elevation, wave exposure, and distance to harbours or sources of urban/organic pollution. Kelaher et al. (2007) also found that differences between sites separated by 20 to $50 \mathrm{~m}$ accounted for only a relatively small proportion of total variation in molluscan assemblages from coralline turfs in Patagonia.

Kelaher et al. (2007) reported that species richness of molluscan assemblages associated with Patagonian coralline turfs varied significantly among shores, but they found no evidence for a strong latitudinal gradient, a fact that appears inconsistent with our results. It is worth noting, however, that the 3 northernmost shores sampled by Kelaher et al. (2007) were located within Golfo San Matías. This relatively warm environment (Guerrero \& Piola 1997) is populated by a rich assemblage of molluscan species (Scarabino 1977), many of which attain their southern limit of distribution in 
Table 4. SIMPER test for significant contrasts between provinces and localities. Species lists were truncated whenever cumulative percentage reached $50 \%$. Bi: bivalve, Po: polychaete, Is: isopod, Ne: nemertean, Ta: tanaidacean, Tu: tunicate, De: decapod, Pl: planarian, Am: amphipod, Hy: hydrozoan, Py: pycnogonid, Sp: sponge

\begin{tabular}{|c|c|c|c|c|c|c|}
\hline Species & Group & $\begin{array}{l}\text { Average } \\
\text { abundance }\end{array}$ & $\begin{array}{c}\text { Average } \\
\text { abundance }\end{array}$ & $\begin{array}{c}\text { Average } \\
\text { dissimilarity }\end{array}$ & $\begin{array}{l}\% \text { contribution } \\
\text { to dissimilarity }\end{array}$ & $\begin{array}{c}\text { Cumulative \% } \\
\text { contribution }\end{array}$ \\
\hline \multicolumn{7}{|l|}{ Average dissimilarity $=90.09$} \\
\hline & & Buenos Aires & Chubut & & & \\
\hline Brachidontes rodriguezii & $\mathrm{Bi}$ & 1215.25 & 0.00 & 6.12 & 6.79 & 6.79 \\
\hline Rhynchospio glutaea & Po & 0.25 & 520.16 & 4.60 & 5.11 & 11.90 \\
\hline Perumytilus purpuratus & $\mathrm{Bi}$ & 0.00 & 240.68 & 3.95 & 4.38 & 16.28 \\
\hline Caulleriella alata & Po & 0.00 & 162.25 & 3.56 & 3.96 & 20.24 \\
\hline Exogoninae sp. 1 & Po & 0.05 & 124.41 & 3.34 & 3.71 & 23.95 \\
\hline Sphaerosyllis sp. & Po & 0.00 & 95.08 & 3.24 & 3.59 & 27.54 \\
\hline Platynereis magalhaensis & Po & 0.00 & 67.15 & 2.92 & 3.24 & 30.78 \\
\hline Erinaceusyllis sp. & Po & 0.10 & 57.34 & 2.64 & 2.93 & 33.71 \\
\hline Proscoloplos sp. & Po & 0.00 & 44.14 & 2.46 & 2.73 & 36.44 \\
\hline Exosphaeroma lanceolata & Is & 0.00 & 36.29 & 2.45 & 2.72 & 39.16 \\
\hline Syllinae sp. 1 & Po & 0.00 & 31.38 & 2.44 & 2.70 & 41.86 \\
\hline Marphysa aenea & Po & 0.00 & 25.75 & 2.32 & 2.57 & 44.43 \\
\hline Thelepus sp. & Po & 0.00 & 29.08 & 2.29 & 2.54 & 46.97 \\
\hline Nemertea sp.2 & $\mathrm{Ne}$ & 0.00 & 15.10 & 2.07 & 2.30 & 49.27 \\
\hline Capitella sp. & Po & 0.00 & 19.69 & 2.00 & 2.22 & 51.48 \\
\hline \multicolumn{7}{|l|}{ Average dissimilarity $=44.34$} \\
\hline & & Quequén & Necochea & & & \\
\hline Nemertea sp.1 & $\mathrm{Ne}$ & 22.00 & 1.50 & 3.17 & 7.15 & 7.15 \\
\hline Pseudonototanais sp. & $\mathrm{Ta}$ & 16.60 & 0.10 & 2.80 & 6.32 & 13.47 \\
\hline Molgula pyriformis & $\mathrm{Tu}$ & 3.70 & 0.00 & 2.79 & 6.28 & 19.76 \\
\hline Halicarcinus planatus & $\mathrm{De}$ & 4.50 & 0.00 & 2.69 & 6.06 & 25.82 \\
\hline Lineus bonaerensis & $\mathrm{Ne}$ & 8.40 & 5.30 & 2.55 & 5.75 & 31.57 \\
\hline Notoplana sp. & Pl & 7.40 & 0.90 & 2.44 & 5.49 & 37.07 \\
\hline Typosyllis prolixa & Po & 75.60 & 43.50 & 2.31 & 5.20 & 42.27 \\
\hline Caprella dilatata & $\mathrm{Am}$ & 11.00 & 0.80 & 2.23 & 5.02 & 47.29 \\
\hline Perinereis cf. cultrifera & Po & 17.80 & 4.30 & 2.11 & 4.76 & 52.05 \\
\hline \multicolumn{7}{|l|}{ Average dissimilarity $=38.30$} \\
\hline & & C. Rivadavia & Rada Tilly & & & \\
\hline Orbiniidae sp. 1 & Po & 0.00 & 22.43 & 1.48 & 3.86 & 3.86 \\
\hline Galleomatoidea sp. 1 & $\mathrm{Bi}$ & 58.80 & 3.80 & 1.23 & 3.20 & 7.07 \\
\hline Rhynchospio glutaea & Po & 823.30 & 217.03 & 1.22 & 3.19 & 10.25 \\
\hline Petricola dactylus & $\mathrm{Bi}$ & 0.40 & 18.83 & 1.18 & 3.07 & 13.32 \\
\hline Obelia longissima & Hy & 0.00 & 13.00 & 1.16 & 3.04 & 16.36 \\
\hline Achelia sp. & Py & 1.00 & 21.73 & 1.06 & 2.77 & 19.13 \\
\hline Edotia tuberculata & Is & 6.90 & 0.00 & 1.05 & 2.75 & 21.88 \\
\hline Potamilla sp. & Po & 0.20 & 11.03 & 1.02 & 2.66 & 24.53 \\
\hline Leucandra sp. & $\mathrm{Sp}$ & 0.10 & 16.15 & 0.99 & 2.59 & 27.13 \\
\hline Cirratulidae sp. 1 & Po & 3.30 & 13.25 & 0.91 & 2.37 & 29.50 \\
\hline Paramoera sp. & Am & 6.10 & 0.00 & 0.90 & 2.36 & 31.86 \\
\hline Syllis gracilis & Po & 8.00 & 64.03 & 0.90 & 2.35 & 34.21 \\
\hline Exogoninae sp. 1 & Po & 206.20 & 42.63 & 0.88 & 2.30 & 36.50 \\
\hline Caulleriella alata & Po & 250.50 & 74.00 & 0.87 & 2.28 & 38.78 \\
\hline Pherusa sp. & Po & 0.00 & 2.80 & 0.80 & 2.10 & 40.88 \\
\hline Perumytilus purpuratus & $\mathrm{Bi}$ & 110.70 & 370.65 & 0.80 & 2.08 & 42.96 \\
\hline Dispio sp. & Po & 16.20 & 2.80 & 0.79 & 2.07 & 45.03 \\
\hline Corophium cf. bonelli & $\mathrm{Am}$ & 2.10 & 19.20 & 0.79 & 2.05 & 47.08 \\
\hline Erinaceusyllis sp. & Po & 94.70 & 19.98 & 0.78 & 2.03 & 49.12 \\
\hline Halosydna patagonica & Po & 0.00 & 1.93 & 0.73 & 1.90 & 51.02 \\
\hline
\end{tabular}

this semi-enclosed Patagonian gulf. On the other hand, present and previous studies (e.g. Ieno \& Bastida 1998) have recorded low levels of benthic biodiversity on the open coast of Buenos Aires province.
Mytilid bivalves and polychaetes were the most important macrofaunal organisms explaining differences in structure at the scale of provinces. A different mytilid species characterized each province, viz. Bra- 
chidontes rodriguezii and Perumytilus purpuratus were found only in samples from Buenos Aires or Chubut, respectively, without overlapping distributions. Examination of material from the national collection of invertebrates stored at the Museo Argentino de Ciencias Naturales (N. Landoni, pers. comm.) confirmed this pattern. $P$. purpuratus is the dominant intertidal mytilid in the Malvinas/Falkland Islands, Tierra del Fuego and Santa Cruz provinces, and also along the southern and central open coasts of Chubut (i.e. 43 to $\left.55^{\circ} \mathrm{S}\right)$. On the other hand, B. rodriguezii dominates mid-intertidal rocky shores of Buenos Aires province and Golfo San Matías (37 to $42^{\circ} \mathrm{S}$ ). The species coexist at least between 42 and $43^{\circ} \mathrm{S}$ (Golfo San Matías, San José and Nuevo), with $P$. purpuratus occupying higher intertidal levels than $B$. rodriguezii at sites where they co-occur (Sánchez \& Zaixso 1995). Further studies may demonstrate that the transitional zone where these 2 mytilids co-occur is actually greater than presently recognized.

We found a significant correlation between beta diversity and distance only at scales of $10^{4} \mathrm{~m}$ or higher. The extremely high taxonomic turnover in pairwise comparisons between samples belonging to different provinces indicates an almost complete faunal change at the scale of $10^{6} \mathrm{~m}$. The Bray-Curtis similarity index also decreased significantly at the scale of different localities within the same province, but not at the 2 smallest scales. Previous studies in the marine environment have not always shown a clear relationship between beta diversity and scale. In soft-sediment macrobenthic communities from the continental shelf off Norway (Ellingsen \& Gray 2002), beta diversity was higher at the largest scale (1958 $\mathrm{km}$ ) than at scales lower than $100 \times 260 \mathrm{~km}$. Other studies carried out in the same environment (Ellingsen 2002) reported that adjacent sites did not share significantly more species than site pairs separated by distances of up to $130 \mathrm{~km}$, and that beta diversity was more strongly related to environmental changes than to spatial distance between sites. Winberg et al. (2007) found that beta diversity of estuarine tidal flat macrobenthos was highest at intermediate scales. A survey of soft-sediment assemblages in a coral lagoon (Schlacher et al. 1998) reported that the number of shared species between all pairwise permutations of sites was low and weakly related to distance at a scale of $18 \times 11 \mathrm{~km}$. A study of echinoderms in the Indo-West Pacific (Izsak \& Price 2001) even found an inverse relationship between beta diversity and spatial scale.

In conclusion, our study shows that although significant differences in species richness, diversity, evenness and structure of macrofaunal assemblages associated with intertidal coralline turfs were found at various scales, changes observed between provinces were by far the greatest and reflect an almost complete replacement between warm-temperate and cold-temperate biotas of different origin in the southwestern Atlantic.

Acknowledgements. We are grateful to CONICET (PIP No. 02126 to J.L.G.) and ANPCYT (PICT 2002 No. 11180 to D. Roccatagliata) for financial support. R. Becerra gave us advice on measuring distances with GIS software. Bivalves, amphipods, the ascidian Molgula pyriformis and the tanaidacean Pseudonototanais sp. were identified by D. Zelaya, G. Alonso, M. Varela and D. Roccatagliata, respectively. H. Zaixso and N. Landoni showed us how to distinguish Perumytilus purpuratus from Brachidontes rodriguezii. A. Rico and R. Peralta helped during field work at Comodoro Rivadavia and Rada Tilly. 3 anonymous referees made valuable comments on an earlier version of this manuscript.

\section{LITERATURE CITED}

Bastida R, Roux A, Martínez DE (1992) Benthic communities of the Argentine continental shelf. Oceanol Acta 15: $687-698$

> Bayne BL (1964) Primary and secondary settlement in Mytilus edulis L. (Mollusca). J Anim Ecol 33:513-523

Bertness MD, Crain CM, Silliman BR, Bazterrica MC, Reyna MV, Hidalgo F, Farina JK (2006) The community structure of western Atlantic Patagonian rocky shores. Ecol Monogr 76:439-460

Bussell JA, Lucas IAN, Seed R (2007) Patterns in the invertebrate assemblage associated with Corallina officinalis in tide pools. J Mar Biol Assoc UK 87:383-388

Chapman MG, People J, Blockley D (2005) Intertidal assemblages associated with natural Corallina turf and invasive mussel beds. Biodivers Conserv 14:1761-1776

Clarke A (1992) Is there a latitudinal diversity cline in the sea? Trends Ecol Evol 7:286-287

Clarke KR, Warwick RM (1994) Change in marine communities: an approach to statistical analysis and interpretation. Natural Environment Research Council, Plymouth

> Daleo P, Escapa M, Alberti J, Iribarne O (2006) Negative effects of an autogenic ecosystem engineer: interactions between coralline turf and an ephemeral green alga. Mar Ecol Prog Ser 315:67-73

Denny MW, Helmuth B, Leonard GH, Harley CDG, Hunt LJH, Nelson EK (2004) Quantifying scale in ecology: lessons from a wave-swept shore. Ecol Monogr 74: 513-532

Ellingsen KE (2002) Soft-sediment benthic biodiversity on the continental shelf in relation to environmental variability. Mar Ecol Prog Ser 232:15-27

> Ellingsen KE, Gray JS (2002) Spatial patterns of benthic diversity: is there a latitudinal gradient along the Norwegian continental shelf? J Anim Ecol 71:373-389

Fernández M, Jaramillo E, Marquet PA, Moreno CA and others (2000) Diversity, dynamics and biogeography of Chilean benthic nearshore ecosystems: an overview and guidelines for conservation. Rev Chil Hist Nat 73:797-830

> Fletcher DJ, Underwood AJ (2002) How to cope with negative estimates of components of variance in ecological field studies. J Exp Mar Biol Ecol 273:89-95

Graham MH, Edwards MS (2001) Statistical significance versus fit: estimating the importance of individual factors in ecological analysis of variance. Oikos 93:505-513 
Gray JS (1997) Marine biodiversity: patterns, threats and conservation needs. Biodivers Conserv 6:153-175

Gray JS (2000) The measurement of marine species diversity, with an application to the benthic fauna of the Norwegian continental shelf. J Exp Mar Biol Ecol 250:23-49

Gray JS (2001) Antarctic marine benthic biodiversity in a world-wide latitudinal context. Polar Biol 24:633-641

Guerrero RA, Piola AR (1997) Masas de agua en la plataforma continental. In: Boschi E (ed) El mar argentino y sus recursos pesqueros, Vol 1. Instituto Nacional de Investigación y Desarrollo Pesquero, Mar del Plata, p 107-118

Ieno EN, Bastida RO (1998) Spatial and temporal patterns in coastal macrobenthos of Samborombon Bay, Argentina: a case study of very low diversity. Estuaries 21:690-699

Izsak C, Price ARG (2001) Measuring $\beta$-diversity using a taxonomic similarity index, and its relation to spatial scale. Mar Ecol Prog Ser 215:69-77

Jones CG, Lawton JH, Shachak M (1994) Organisms as ecosystem engineers. Oikos 69:373-386

Kelaher BP (2002) Influence of physical characteristics of coralline turf on associated macrofaunal assemblages. Mar Ecol Prog Ser 232:141-148

Kelaher BP (2003) Changes in habitat complexity negatively affect diverse gastropod assemblages in coralline algal turf. Oecologia 135:431-441

Kelaher BP, Underwood AJ, Chapman MG (2003) Experimental transplantations of coralline algal turf to demonstrate causes of differences in macrofauna at different tidal heights. J Exp Mar Biol Ecol 282:23-41

Kelaher BP, Castilla JC, Seed R (2004) Intercontinental test of generality for spatial patterns among diverse molluscan assemblages in coralline algal turf. Mar Ecol Prog Ser 271: 221-231

Kelaher BP, Castilla JC, Prado L, York P, Schwindt E, Bortolus A (2007) Spatial variation in molluscan assemblages from coralline turfs of Argentinean Patagonia. J Molluscan Stud 73:139-146

Koleff P, Gaston KJ, Lennon JJ (2003) Measuring beta diversity for presence-absence data. J Anim Ecol 72:367-382

Lawver LA, Gahagan LM (2003) Evolution of Cenozoic seaways in the circum-Antarctic region. Palaeogeogr Palaeoclimatol Palaeoecol 198:11-37

López Gappa J (2000) Species richness of marine Bryozoa in the continental shelf and slope off Argentina (south-west Atlantic). Divers Distrib 6:15-27

López Gappa J, Tablado A (1997) Growth and production of

Editorial responsibility: Matthias Seaman,

Oldendorf/Luhe, Germany an intertidal population of the chiton Plaxiphora aurata (Spalowski, 1795). Veliger 40:263-270

López Gappa J, Alonso GM, Landoni NA (2006) Biodiversity of benthic Amphipoda (Crustacea: Peracarida) in the Southwest Atlantic between $35^{\circ} \mathrm{S}$ and $56^{\circ} \mathrm{S}$. Zootaxa 1342:1-66

Martínez S, del Río CJ (2002) Late Miocene mollusks from the southwestern Atlantic Ocean (Argentina and Uruguay): a palaeobiogeographic analysis. Palaeogeogr Palaeoclimatol Palaeoecol 188:167-187

Mendoza ML (2002) Presencia del género Jania Lamouroux (Rhodophyta, Corallinales) para la costa de la Argentina. Naturalia Patagónica 1:51-59

Piola AR, Rivas AL (1997) Corrientes en la plataforma continental. In: Boschi E (ed) El mar argentino y sus recursos pesqueros, Vol 1. Instituto Nacional de Investigación y Desarrollo Pesquero, Mar del Plata, p 119-132

Rosenzweig ML (1995) Species diversity in space and time. Cambridge University Press, Cambridge

Roy K, Jablonski D, Valentine JW, Rosenberg G (1998) Marine latitudinal diversity gradients: tests of causal hypotheses. Proc Natl Acad Sci USA 95:3699-3702

> Roy K, Jablonski D, Valentine JW (2000) Dissecting latitudinal diversity gradients: functional groups and clades of marine bivalves. Proc R Soc Lond B Biol Sci 267:293-299

Sánchez V, Zaixso HE (1995) Secuencias de recolonización mesolitoral en una costa rocosa del Golfo San José (Chubut, Argentina). Nat Patag Cienc Biol 3:57-83

Scarabino V (1977) Moluscos del Golfo San Matías. Inventario y claves para su identificación. Comunicaciones de la Sociedad Malacológica del Uruguay 4:177-285

Schlacher TA, Newell P, Clavier J, Schlacher-Hoenlinger MA, Chevillon C, Britton J (1998) Soft-sediment benthic community structure in a coral reef lagoon - the prominence of spatial heterogeneity and 'spot endemism'. Mar Ecol Prog Ser 174:159-174

> Valdovinos C, Navarrete SA, Marquet PA (2003) Mollusk species diversity in the Southeastern Pacific: why are there more species towards the pole? Ecography 26:139-144

Whittaker RH (1975) Communities and ecosystems. MacMillan, New York, NY

> Winberg PC, Lynch TP, Murray A, Jones AR, Davis AR (2007) The importance of spatial scale for the conservation of tidal flat macrobenthos: an example from New South Wales, Australia. Biol Conserv 134:310-320

Zar JH (1996) Biostatistical analysis, 3rd edn. Prentice Hall, Upper Saddle River, NJ

Submitted: September 3, 2007; Accepted: February 13, 2008 Proofs received from author(s): June 19, 2008 